\title{
Effect of Artificial Heating on Cold Resistance of the Asian Pear Cultivars 'Chuwhangbae' and 'Niitaka' During Winter Period
}

\author{
Sherzod Rajametov ${ }^{2}$, Sam-Seok Kang ${ }^{1}$ * \\ ${ }^{1}$ Pear Research Station, NIHHS, RDA, Naju 520-821, Korea \\ ${ }^{2}$ Uzbek Research Institute of Plant Industry, UzSPCA, Tashkent 111202, Uzbekistan
}

\begin{abstract}
The purpose of this study was to investigate responses of pear cultivars 'Niitaka' and 'Chuwhangbae' under short period heating on cold resistance level of flower buds. Experiment was conducted using annual shoots flower bud which were artificially heated $(\mathrm{AH})$ during 72 hour at room condition $\left(18-20^{\circ} \mathrm{C}\right)$. To assay for cold resistance, the cultivars were treated and observed under negative temperatures $-10,-15,-20$ and $-25^{\circ} \mathrm{C}$ during the winter period in 2012 and 2013 . Our findings revealed that 'Chuwhangbae' which was treated under control and artificial heating treatments was more resistant to low temperature than 'Niitaka' showing decreasing level of flower buds damages by mid-January although in early March an increasing level of damages was observed again. Cold resistant cultivar 'Chuwhangbae' responded more sensitively to external environments. This means that 'Chuwhangbae' restructures the plant protoplasts and process the transition to the new metabolic energy level in an efficient manner when triggered by effective negative temperatures thereby resulting in hardening process. We assume that this might be closely related with dormancy period, concentration of the mineral elements, water potential and transition processes of metabolism to the new energetic level. With a rise in temperature, cold tolerance in pear cultivars significantly decreased and this is related to intensive development of the floral organs. The chilling requirements for blossoming of 'Niitaka' was higher than 'Chuwhangbae'.
\end{abstract}

Keywords Flower bud, Dormancy, Cold resistance, Cold injury, Artificial heating

\section{INTRODUCTION}

Among the critical factors which have a direct impact on the condition and the subsequent freezing of the plants in winter is not only the complexity of damaging temperatures but also important change in terms of the water balance and physiochemical metabolism in vegetative and generative organs.

During the intensification of the horticulture the problem of increasing hardiness in fruit trees is of particular relevance. The fruit trees undergoing physiological vital activity that are repeatedly exposed to low temperature, are more likely vulnerable from the damaging effect of frosts. A key for a successful pear cultivation in each zone is the selection of varieties that are suitable to the local climate. Whereas some cultivars of pear undergo insufficient winter hardiness (Krasova 1997; Guchapshev et al. 2006;
Satibalov et al. 2008).

A very important characteristic for the survival of pear trees in winter is having the ability to speed up frost hardiness during cold weather. Avoidance of the injuries is demonstrated only by plants, which has the rate of hardening exceeds the rate of growth of frost during the invasion of cold air masses. Sudden fluctuations in temperature with large amplitude caused considerable damage to trees, and in some cases are lethal. If thawing would be held under slow and smooth decline in air temperature, plant organs can recover well (Guchapshev et al. 2006; Satibalov et al. 2008).

Knowledge about cultivation of the pear trees under specific climatic conditions with high fluctuation of temperature during winter period and where minimal temperature might reach below $-20^{\circ} \mathrm{C}$ which sustains for long time is a necessary requirement in addition to the

Received March 20, 2014; Revised March 25, 2014; Accepted March 27, 2014; Published March 31, 2014

*Corresponding author Sam-Seok Kang, npssk014@rda.go.kr, Tel: +82-61-330-1540, Fax: +82-61-330-1542 
knowledge on the biological characteristics, such as cold resistance in cultivars.

A variety of physiological and biochemical alterations, such as changes in carbohydrate, lipid and protein composition and water status in plants have been correlated with cold acclimation, where in upon occurrence of negative temperature, an increase of sugars in plant tissues occurs due to hydrolysis of starch and association with cold hardiness (Sparks et al. 2001; Lee 2011). During this period, the accumulation of significant amounts of a special type of sugar occurs. These substances hinder the appearance of ice crystals in the cells during severe frosts which results in slow growth (Ashworth 1992; Sugiura 2002; Liu et al. 2007; Satibalov et al.2008), although a clear role for any of these changes in development of freezing tolerance is yet to be demonstrated. Consequently, accumulation of proteins has been suggested to play a role in the observed increase in freezing tolerance (Mohapatra et al. 1987; Perras and Sarhan 1989; Alehina et al. 2005). However, most of the injury results from the severe cellular dehydration that occurs with freezing (Levitt 1980a).

The mechanisms responsible for freezing tolerance (Thomashow 1998) and inhibition of growth during the deep dormancy are not completely clear. Some researchers tend to attribute this phenomenon to naringenin and abscisic acid (ABA) as specific substances with extensive inhibitory effect and are freezing-tolerant (Genkel et al. 1964; Likhonos et al. 1983; Grossi et al. 1992; Lang et al. 1994; Thorlby et al. 2004; Lata and Prasad 2011).

Nevertheless, the role of ABA in low-temperatureresponsive gene expression is not clear (Thomashow 1999; Shinozaki and Yamaguchi-Shinozaki 2000). Although several genes are induced in response to dehydration and cold stress on exogenous ABA treatment (Zhu 2002; Shinozaki et al. 2003; Lata and Prasad 2011), there are also many genes that do not respond to such treatments (Ingram and Bartels 1996; Shinozaki and Yamaguchi-Shinozaki 1997; Zhu 2002; Yamaguchi-Shinozaki and Shinozaki 2005) suggesting the existence of both ABA-dependent and -independent signal transduction cascades. DRE/CRT is one of the major cis-acting elements which function in ABA- responsive or non-responsive gene expression during abiotic stresses (Nakashima and Yamaguchi-
Shinozaki 2010; Lata and Prasad 2011). ABA can substitute for the low temperature stimulus, provided there is also an adequate supply of sugars and there may be ABA-dependent and ABA-independent pathways involved in the acclimation process (Gusta et al. 2005).

Winter hardiness is one of the most important properties of the fruit crops, limiting their successful cultivation, thus it is very important to find ways to limit injury by frosts. Research on plant adaptation to adverse conditions such as cold and freezing must be pursued.

Analysis of literature shows that the resistance of plants to cold is depending on many factors. This experiment was carried out to investigate the response of pear cultivars on the artificial heating during winter period and the subsequent effect on the flower buds.

\section{MATERIALS AND METHODS}

\section{Plant materials and artificial heating treatment}

The experiment was done in Pear Research Station, NIHHS, RDA, Republic of Korea. Cold tolerance of flower buds in two cultivars of Pyrus pyrifolia, 'Chuwhangbae' and 'Niitaka,' was investigated under two state: first is the artificial freezing of the annual shoots directly from the field as control and second is freezing of the annual shoots after artificial heating treatment. Artificial heating was performed by keeping the shoots for 72 hours at $18-20^{\circ} \mathrm{C}$.

\section{Evaluation for cold stress resistance}

The shoots we used had at least 15-18 flower buds. Each shoot had about $0.80-1.0 \mathrm{~m}$ in length with a diameter of 0.7-1.0 $\mathrm{mm}$. Each treatment was replicated thrice.

Freezing of annual shoots was carried out using the refrigerator (SJ-501GM-LED). Pre-hardening of the annual shoots with flower buds previously under control and artificial heating state was done by keeping them at $0^{\circ} \mathrm{C}$ for 6 hours, and then the temperature was slowly decreased during an hour until $-2^{\circ} \mathrm{C}$ and held for 2 hours. Starting at the third hour of freezing under $-2^{\circ} \mathrm{C}$, the temperature was decreased at $-2^{\circ} \mathrm{C}$ interval per hour and held for 4 hours until a certain target incubation temperature $(-10,-15,-20$ 
and $-25^{\circ} \mathrm{C}$ ) was reached and held for 6 hours. After freezing in the refrigerator the temperature condition was raised slowly to $0^{\circ} \mathrm{C}$ by using $2{ }^{\circ} \mathrm{C}$ increase interval per hour. At zero temperature, shoots were kept at least for 6 hours to complete thawing process. Hereinafter, the temperature was raised slowly every hour to $2^{\circ} \mathrm{C}$ up to room temperature. Subsequently, the shoots were transferred into container with water for saturation. Shoots were kept at room temperature for 2 days to observe the damage inflicted by cold treatment. Extent of damage was done by cutting off the flower buds into sections.

Buds with a dark-brown or black colored pestle or bottom were considered dead, and the degree of hardiness is characterized by the percentage of live uninjured buds out of the total number of buds in a shoot.

\section{The climatic change of winter season 2012 and 2013.}

In South Korea, although the autumn period are usually relatively warm and long, there are years with the early onset of frosts. According to perennial data, the first frosts in the region begin in mid-November which coincided with the conduct of our experiment where temperature went down to $-0.6^{\circ} \mathrm{C}$ which further decreased to a minimum $-3.8^{\circ} \mathrm{C}$ (Fig. 1) in the late November.

However, the average and maximal daily temperatures were significantly high in that period. From early December the average and minimal daily temperatures were slowly decreasing and reached a minimum by mid-January at -6.2 and $-12.9^{\circ} \mathrm{C}$, respectively. Thereafter the maximum temperature started to decrease and was kept about $8.0-11.0^{\circ} \mathrm{C}$ and the duration of the warm weather was insignificantly long. It should be noted that the average and minimal daily temperatures were lower than on perennial data. Afterward, from late January to early March, the average and minimal daily temperatures were increasing and a rise in maximal temperature over $15.0^{\circ} \mathrm{C}$ was noted whereas the minimal temperature was about -7.0 and $-10^{\circ} \mathrm{C}$. By comparing with perennial data, the average daily temperature in winter period was relatively low.

\section{RESULTS}

Many researchers investigated the degree of plant's resistance to adverse winter conditions only by directly freezing the whole plant or its organs during the winter. And it should be noted that most of the experiments were done in a specific and limited period of winter, which resulted to different findings (Sperry et al. 1994; Sparks et al. 2000, 2001; Guchapshev et al. 2006; Liu et al. 2007; Rezvyakova, 2008; Lee et al. 2011; Rajametov et al. 2011; Yim et al. 2011; Kim et al. 2012, Krasova et al. 2012). In this study, we used different negative temperatures as well as short provocative thawing process through timely



Fig. 1. Temperature conditions in winter period, Naju 2012-2013. 
temperature adjustments to study response of plant to direct freezing during winter.

We identified the critical level of damage in flower buds using the minimum temperature $\left(-10^{\circ} \mathrm{C}\right)$ which was slowly reduced further to $-20^{\circ} \mathrm{C}$. In 'Chuwhangbae' the respective initial injury percentage of floral organs precondition in control and artificial heating state were 0.0 and $6.7 \%$, under $-10^{\circ} \mathrm{C}$ (Fig. 2). The resistance tendency in 'Chuwhangbae' was relatively higher than in Niitaka which showed an initial corresponding damage rate at 38.1 and $57.7 \%$, respectively. When temperature was further lowered to freezing temperature $\left(-20^{\circ} \mathrm{C}\right)$, both cultivars showed an increase in damaging rate but the level was more critical in 'Niitaka' than in 'Chuwhangbae' which showed relatively lower injury rate at 57.1 and $80.9 \%$, for both control and AH treatment, respectively. Between -10 and $-20^{\circ} \mathrm{C}$, both cultivars showed intermediate degree of tolerance but overall, 'Niitaka' had higher injuries than 'Chuhwangbae'.

With the decline of the average daily and minimum temperature, the rate of hardiness of both cultivars was increasing regardless of treatments although a varietal difference was observed in this parameter. This could be due to the physiological processes in plant undergoing deep dormancy condition to reduce relatively vital activity of all organs.

A maximal cold resistance and minimal damaging in cultivars was identified under -10 and $-15^{\circ} \mathrm{C}$ consequently regardless of treatment during January. By mid-January resistance of cultivars was higher while the average and minimal air temperature outside reached -6.2 and $-12.9^{\circ} \mathrm{C}$, respectively. 'Chuwhangbae' flower buds exhibited some degree of tolerance showing no injury in control by freezing to -20 and $-25^{\circ} \mathrm{C}$, whereas in 'Niitaka' respective damaging at the rate of 9.0 and $15.8 \%$ were detected. In both cultivars, however, floral organs damage significantly differed between control and under artificial heating state. Vulnerability to frost was more pronounced in 'Niitaka' where injury level was 47.6 and $96.3 \%$, respectively for the control and AH state, while 'Chuwhangbae' had lower level of injury at 9.9 and $28.4 \%$, respectively.
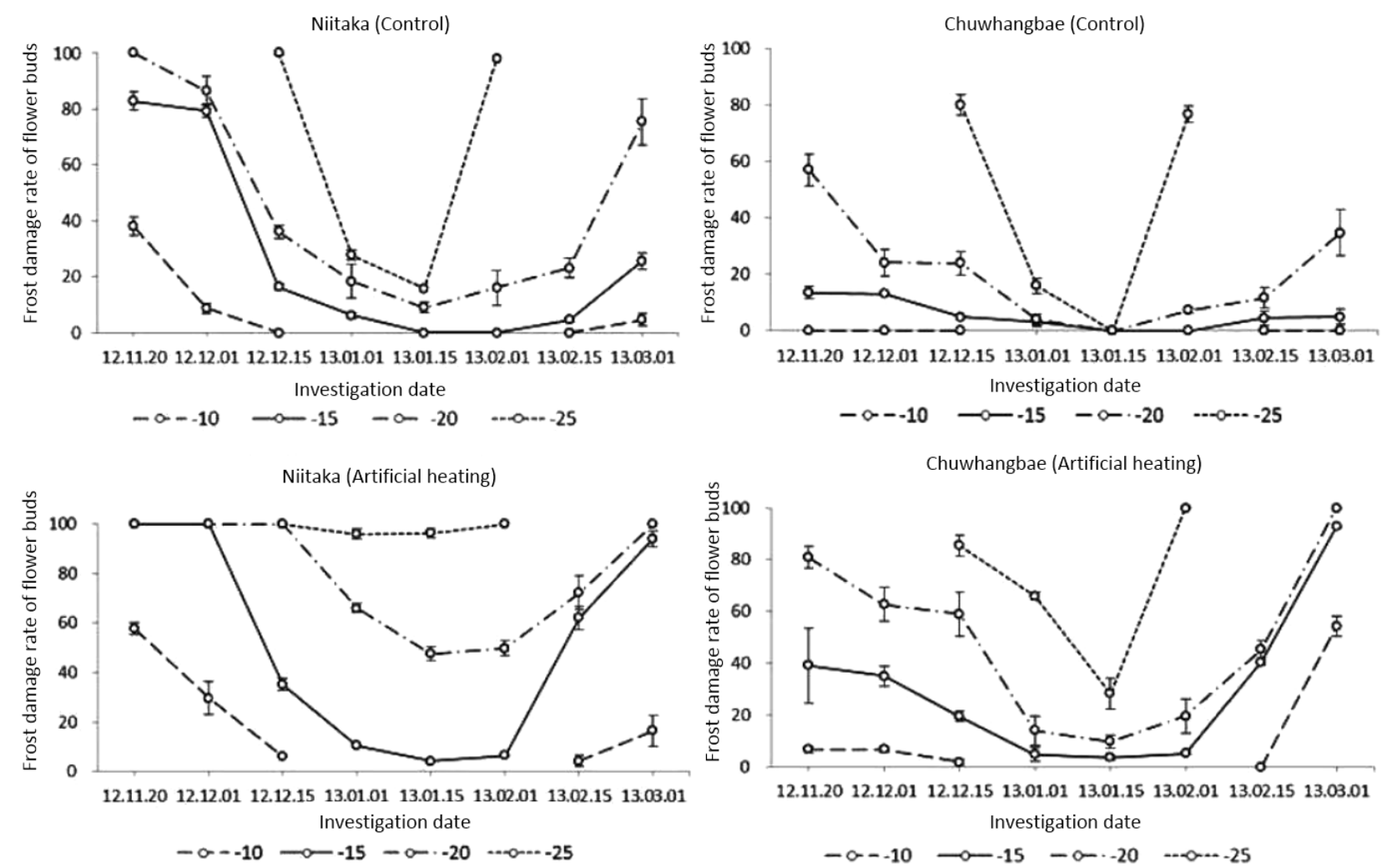

Fig. 2. Frost damages of flower buds in control and after artificial heating treatment $\left({ }^{\circ} \mathrm{C}\right)$ during winter period. Data represented by Mean \pm SD $(\mathrm{n}=3)$. 
A subsequent rise in temperature in nature resulted in a decrease of cold tolerance in pear cultivars which happened at the onset of dormancy period, which led to an increase in injury rate especially observed during February. This is related with breaking of dormancy and intensively development of the floral organs (Fig. 3), which was remarkable in 'Chuwhangbae' which started to develop early in comparison with 'Niitaka'. Thus, freezing treatment $\left(-25^{\circ} \mathrm{C}\right)$ in the early February was critical for both cultivars regardless of states where injury degrees in 'Niitaka' reached $100 \%$ and in 'Chuwhangbae' was over $80 \%$.

In early March, initial injuries of the control 'Chuwhangbae' and 'Niitaka' were found to be 0.0 and $4.6 \%$, respectively under freezing at $-10^{\circ} \mathrm{C}$, but under $\mathrm{AH}$ condition, both cultivars had a relatively higher injury rate of 54.3 and $16.4 \%$, respectively. By reducing the temperature to $-20^{\circ} \mathrm{C}$, the level of injuries was rapidly increased. Under control state, both cultivars had 34.8 and $75.4 \%$ damages, respectively, whereas in $\mathrm{AH}$ states all cultivars were fully damaged.

Our results showed that regardless of cultivars, the frost hardiness rate was significantly lower prior to deep dormancy and after breaking it down. A maximum resistance to freezing was determined from late December until late January but the difference of damaging level of cultivars were at the same level. Presumably the deep dormancy period in the plants occurred from late December until late January. This is due to lesser degree of damages observed, although the deep dormancy duration and cold tolerance level were different in cultivars regardless of extent of cold and freezing condition. And pear cultivars significantly react differently to the provocative action of thawing. 'Chuwhangbae' respond to external condition positively whereas 'Niitaka' had negatively responded to the stress with higher level of injury.

\section{DISCUSSION}

According to our results 'Chuwhangbae' was more resistant to low negative temperature during winter period in comparison with 'Niitaka' under short period of heating or by fluctuation of temperature under natural condition. The cold resistant 'Chuwhangbae' responds more sensitively to external environments. It means that 'Chuwhangbae' restructures the plant protoplasts and the transition process to the new metabolic energy level, more effectively compared to 'Niitaka', when triggered by negative temperatures thereby resulting in hardening process. We assume that it might be closely related with the stage and duration of dormancy, concentration of the mineral elements, water potential and transition processes of metabolism to the new energetic level.

In comparison with the study on pear in in Tashkent region (Uzbekistan), archespores development in spur shoots was found to relate to different resistance of the

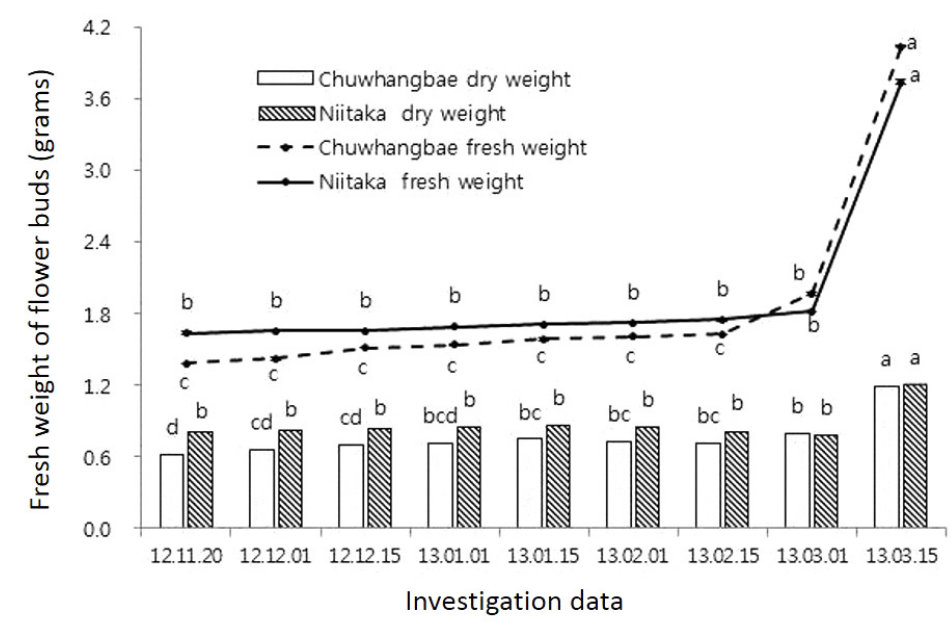

Fig. 3. Intensity of the flower buds growth during winter period, g (per 10 buds). Mean separation within columns by Duncan's multiple range test, $P \leq 0.05$. 
cultivars to low temperature during winter (Rajametov and Baymetov 2010) and it was concluded that the chilling requirement for blossoming is considered as innate features of cultivars. If the plants in the archespore stage during dormancy period cannot obtain the required temperature, the developing floral organs will be vulnerable to damage by low temperature and then finally the flowering is delayed. And it should be noted that most cultivars in Central Asian and East Asian are known as less resistant to negative temperatures and had more short rest period compared to those with European origin. The dormancybreakdown period in Central and East Asian cultivars was observed in late January and they had significantly higher injury of about $78-80 \%$ under preliminary hardening at $-20^{\circ} \mathrm{C}$ than in European cultivars. The European pear cultivars remained dormant regardless of warm winter or with sharp fluctuations of environment during winter.

Whereas with our experiment under Korean condition at the beginning of February under preliminary hardening $\left(-20^{\circ} \mathrm{C}\right)$, East Asian cultivars 'Chuwhangbae' and 'Niitaka' had moderate injury of about 7 and $16 \%$ respectively, but under artificial heating the rate of damage was 20 to $50 \%$, respectively, which were significantly higher. This means that these plants were at the stage where they are ready to develop for pollen cells but was suddenly hindered by the external low temperature condition forcing the plants to return to dormancy state. Subsequently by early March such tendency was more significantly clearly expressed where level of injury under artificial heating was increased in comparison with control (in the field condition). At this point, 'Chuwhangbae' injury level rapidly increased compared with 'Niitaka' with a remarkable rate difference at $40 \%$. It means that the chilling requirements for blossoming in 'Niitaka' is higher than 'Chuwhangbae' but regardless of chilling requirements the difference of injury level is the same in two cultivars.

Therefore, to give accurate and clear conclusion about plant cold tolerance, finding out critical temperature and initial damaging of individual cultivars is necessary. To carry out such study, the use of shorter period of treatment with a minimum of about 7 or 10 days interval can be explored, complemented with clear priorities on the passage of metabolism and physiological processes in plants during winter.

In general, the mechanism of plant responses to the abiotic stresses such as frosts and to increase the tolerance of the plants is a complex trait genetically programmed, but it manifests itself in certain environmental conditions. We assumed that this is mainly due to combined set of genes which, depending on the changes of the temperature, affects the metabolic functions and development phase of organs. With the changing global climatic condition, breeders have to pay attention to develop cultivars with different ability of tolerance to external environmental condition.

\section{ACKNOWLEDGMENT}

This work was supported by fellowship funds and research project: "Establishment of the foundation of breeding of pear cultivars with a low need of chilling requirement and a late season full blooming in getting warmer climate condition” of NIHHS, RDA, Republic of Korea.

\section{REFERENCES}

Alehina ND, Balnokin YV, Gavrilenko VF. 2005. Plant Physiol. Moscow, Academia. pp. 640 (Russian).

Ashworth EN. 1992. Formation and spread of ice in plant tissues. Hort. Rev. 13: 215-255.

Genkel PA, Oknina EZ. 1964. The rest period and cold resistance of plant. Moscow (Russian).

Grossi M, Cattivelli L, Terzi V, Stanca AM. 1992. Modification of gene expression induced by ABA, in relation to drought and cold stress in barley shoots. Plant Physiol. Biochem. 30: 97-103.

Guchapshev R, Satibalov A. 2006. Winter resistance of pear cultivars under condition of the foothills of the North Caucasus. «Methodological aspects of precision cultivation technology of fruit crops and grapes. Thematic collection of materials of the 75th Anniversary Conference SKZNIISiV. Krasnodar. Issue- I. p. 171-175. (Russian).

Gusta L, Trischuk R, Weiser C. 2005. Plant cold acclimation: The role of abscisic acid. J. Plant Growth Regul. 24: 308-318.

Ingram J, Bartels D. 1996. The molecular basis of dehydration 
tolerance in plants. Annu. Rev. Plant Physiol. Plant Mol. Biol. 47: 377-403.

Kim YK, Kang SS, Won KH, Rajametov Sh, Han JH. 2012. Comparison of Freezing Hardness of Dormant shoots among Japanese Apricot cultivars. Korean J. Hort. Sci. Technol. 30: 114-114.

Krasova NG. 1997. Winter resistance of pear cultivars from VNIISPK. Abstract of scientific-methodological conference: Improving assortment and pear cultivation technology. Orel. p. 43-45. (Russian).

Krasova N, Galasheva A, Golishkina L, Yanchuk T. 2012. Effect of low temperature on cold resistant apple cultivars physiochemical composition. J. Vestnik Orel SAU 3: 86-90.

Lang V, Mantyla E, Welin B. 1994. Alterations in water status, endogenous abscisic acid content, and expression of $r a b 18$ gene during the development of freezing tolerance in Arabidopsis thaliana. Plant Physiol. 104: 1341-1349.

Lata Ch, Prasad M. 2011. Role of DREBs in regulation of abiotic stress responses in plants. J. Exp. Bot. 62: 4731-4748.

Lee JH, Yu DJ, Kim SJ, and Lee HJ. 2011. Changes of cold hardiness and carbohydrate content during cold acclimation in highbush blueberry (Vaccinium corymbosum). Korean J. Hort. Sci. Technol. 29: 47.

Levitt J. 1980a. Responses of Plants to Environmental Stresses: Chilling, Freezing and High Temperature Stresses, Ed 2, Vol 1. Academic Press, New York.

Likhonos FD, Tuz AS, Lobachev AJ. 1983. Flora of cultivated plants. XIV - POME FRUITS, Moskow. pp. 126-225. (Russian).

Liu C, Deng M, Wang W, Li Y, Feng Ch, Yang J. 2007. The study on cold resistance of five species leaf-colored plants of Prunus. J. Agri. Univ. Hebei. 2007-05.

Mohapatra SS, Poole RJ, Dhindsa RS. 1987. Changes in protein patterns and translatable messenger

RNA populations during cold acclimation of alfalfa. Plant Physiol. 82: 733-733.

Nakashima K, Yamaguchi-Shinozaki K. 2010. Promoters and transcription factors in abiotic stress-responsive gene expression. Springer-Verlag. pp. 199-216.

Perras M, Sarhan F. 1989. Synthesis of freezing tolerance proteins in leaves, crown and roots during cold acclimation of wheat. Plant Physiol. 89: 577-585.

Rajametov Sh, Baymetov K. 2010. Features of resistance of pear varieties to low temperatures. J. Agro-ilm. Tashkent.
4: $22-23$

Rajametov Sh, Kim YK, Won KH, and Kang SS. 2011. Cold resistance of pear cultivars in the Republic of Uzbekistan. Korean J. Hort. Sci. Technol. 29: 128.

Rezvyakova S. 2008. Cold resistance of pear cultivars P.ussuriensis. J. Vestnik Orel SAU 4: 86-90.

Satibalov AV, Bekkiev TY. 2008. Winter resistance of pear cultivars under condition of North-Caucasus region. J. Hort. Vitic. 4: 15-16. (Russian).

Shinozaki K, Yamaguchi-Shinozaki K. 1997. Gene expression and signal transduction in water-stress response. Plant Physiol. 115: 327-334.

Shinozaki K, Yamaguchi-Shinozaki K. 2000. Molecular responses to dehydration and low temperature: differences and cross-talk between two stress signaling pathways. Curr. Opin. Plant Biol. 3: 217-223.

Shinozaki K, Yamaguchi-Shinozaki K, Seki M. 2003. Regulatory network of gene expression in the drought and cold stress responses. Curr. Opin. Plant Biol. 6: 410-417.

Sparks JP, Black RA. 2000. Winter hydraulic conductivity and xylem cavitation in coniferous trees from upper and lower treeline. Arct. Alp. Res. 32: 101-106.

Sparks, Jed P, Gaylon S, Campbell R, Black A. 2001. Water content, hydraulic conductivity and ice formation in winter stems of Pinus contorta: a TDR case study. Oecologia 127: 468-475.

Sperry JS, Nichols KL, Sullivan JEM, Eastlack SE. 1994. Xylem embolism in ring-porous, diffuse-porous, and coniferous trees of northern Utah and interior Alaska. Ecology 75: 1736-1752.

Sugiura T. 2002. Dormancy and chilling requirement of deciduous fruit tree. Ser. Agric.Technol. 8: 2-50.

Thomashow MF. 1998. Role of cold-responsive genes in plant freezing tolerance. Plant Physiol. 118: 1-8.

Thomashow MF. 1999. Plant cold acclimation: freezing tolerance genes and regulatory mechanisms.

Annu. Rev. Plant Physiol. Plant Mol. Biol. 50: 571-599.

Yamaguchi-Shinozaki K, Shinozaki K. 2005. Organization of cis-acting regulatory elements in osmotic- and cold stress-responsive promoters. Trends Plant Sci. 10: 88-94.

Yim SH, Choi JH, Choi JJ, Kang SS, Kim YK, Lee HC. 2011. Freezing Hardness according to degree and duration of low temperature in pear cultivars. Korean J. Hort. Sci. Technol. 29: 120.

Zhu JK. 2002. Salt and drought stress signal transduction in plants. Annu. Rev. Plant Biol. 53: 247-273. 